\author{
ANDRZEJ POWAŁOWSKI \\ ORCID: 0000-0002-1232-0605 \\ Uniwersytet Gdański \\ andrzej.powalowski@prawo.ug.edu.pl
}

\title{
Wprowadzenie do aksjologii prawa gospodarczego publicznego
}

\begin{abstract}
Abstrakt: Potrzebna jest refleksja filozoficzna nad prawem gospodarczym publicznym, a w szczególności poczynienie ustaleń dotyczących wartości leżących u podstaw tej dogmatyki. Wartości należy w pierwszej kolejności odpowiednio zidentyfikować i ustalić ich źródła. Problemem jest ich stopień akceptacji przez ustawodawcę, wyrażający się w treści norm stanowionych, oraz rola i znaczenie wartości w procesie stosowania prawa. Wartości określają ład w obszarze gospodarki, wpływają na relacje między organami państwa a przedsiębiorcami oraz na sferę wykonywania działalności gospodarczej. Stanowią też niezbędną przesłankę formułowania zasad prawa. Wolność wykonywania działalności gospodarczej odpowiednio skonfigurowana z potrzebą realizacji interesu publicznego to wartości charakteryzujące i wyróżniające prawo gospodarcze publiczne.
\end{abstract}

Słowa kluczowe: aksjologia, wartości, prawo gospodarcze publiczne, zasady prawa, przedsiębiorcy, ustawodawca.

\section{Uwagi wstępne - o prawie gospodarczym publicznym}

Dociekając początków prawa gospodarczego publicznego, niewątpliwie należy zauważyć najpierw zarysowanie się odrębności gałęziowej prawa gospodarczego jako systemu będącego syntezą elementów prawa publicznego i prywatnego, dokonaną w zakresie przedmiotowym gospodarki ujmowanej (i postrzeganej) w pryzmacie norm regulujących aktywność ekonomiczną różnych podmiotów ${ }^{1}$.

1 Zob. M. Madey, A. Stelmachowski, Zarys prawa gospodarczego, Warszawa 1970; S. Włodyka, Prawo gospodarcze. Zarys systemu. Część ogólna, Warszawa 1981. Na temat genezy prawa gospodarczego w Europie zob. K. Strzyczkowski, Prawo gospodarcze publiczne, Warszawa 2011, s. 45 n. 
Podjęta została dyskusja co do istoty i zakresu prawa gospodarczego, lecz także jego aksjologii i metodologii².

Dopiero później dostrzeżona została możliwość i potrzeba stworzenia płaszczyzny do scalenia w pewną całość wielu instytucji i konstrukcji prawnych o charakterze publicznym, służących przede wszystkim stwarzaniu przez państwo warunków prowadzenia działalności gospodarczej i określenia wzajemnych relacji między państwem a podmiotami tej działalności, a więc normatywnego wyznaczenia systemu oddziaływania państwa na gospodarkę. Powstała tym samym kompleksowa koncepcja prawa gospodarczego publicznego, która w ciągu ostatnich kilkudziesięciu lat podlegała różnym ewolucjom. U początków jej wyodrębnienia badawczego i dydaktycznego w ramach całego systemu prawa legło przekonanie, że celowe i właściwe jest połączenie w obrębie tej dyscypliny głównie elementów prawa administracyjnego i finansowego, z zastrzeżeniem ulokowania w podstawach nauki prawa gospodarczego publicznego także wątków ze sfery ekonomii, finansów oraz organizacji i zarządzania ${ }^{3}$. Zasadnie przyjmowano przy tym, że owe elementy powinny być przejmowane do prawa gospodarczego publicznego $\mathrm{z}$ dobrodziejstwem inwentarza, a więc z całym instrumentarium, zasadami i filozofią wskazanych dogmatyk prawa ${ }^{4}$. Następowała tym samym niejako integracja dyscypliny pod szyldem prawa gospodarczego publicznego.

W ostatnich latach jednak zaczęła pojawiać się tendencja przeciwna. Na gruncie prawa gospodarczego publicznego autonomię uzyskały i umocniły ją dyscypliny szczegółowe. Pojawienie się w szczególności publicznego prawa konkurencji, prawa zamówień publicznych oraz systemów prawa, których przedmiotem regulacji są sektory infrastrukturalne, zapewne stało się przyczyną swoistego „przesunięcia akcentów" na te dyscypliny i odwrócenia uwagi od podstawowych problemów prawa gospodarczego publicznego jako dyscypliny ogólnej.

Niestety zarówno wskazana integracja, jak i proces odwrotny dotyczący prawa gospodarczego publicznego nie sprzyjały refleksji nad prawem gospodarczym publicznym w ogólności. W konsekwencji w sposób — jak się wydaje — niedostateczny określone zostały zasady prawa gospodarczego publicznego, a identyfikacja i wypełnianie treścią form relacji między państwem a gospodarką nie nabrało pożądanej dynamiki. Zdaje się przeto zasadne stanowcze wykazanie, że prawo gospodarcze publiczne stanowi integralną część systemu prawa i jest dogmatyką charakteryzującą się określonymi cechami, mającymi wyróżniające ją znamiona. Być może potrzebna jest refleksja filozoficzna, aby taki efekt osiągnąć.

2 Zob. artykuły zawarte w „Ruchu Prawniczym, Ekonomicznym i Socjologicznym” 1993, nr 1.

3 Tak w szczególności Z. Jaśkiewicz, Prawo zarzadzania gospodarka narodowa (prawo gospodarcze publiczne), Gdańsk 1988; C. Kosikowski, Prawo zarządzania gospodarka narodowa, Warszawa 1991; idem, Prawo gospodarcze publiczne (część ogólna), Łódź 1992.

${ }^{4}$ W tej kwestii zob. J. Grabowski, [w:] System Prawa Administracyjnego, t. 8a. Publiczne prawo gospodarcze, red. J. Grabowski, L. Kieres, A. Walaszek-Pyzioł, Warszawa 2013, s. 19-20. 


\section{Potrzeba zainteresowania się filozofią prawa gospodarczego publicznego}

Refleksja nad prawem w ogólności, a także nad poszczególnymi dogmatykami jest namysłem o charakterze filozoficznym, gdy obejmuje swoim zakresem liczne problemy dla prawa najistotniejsze. Oczywiście ich wybór obarczony jest subiektywizmem z uwagi na osobę dokonującą selekcji tych problemów, choć wybór ten jest też podyktowany ustaleniami poczynionymi przez ustawodawcę i wspartymi ,zbiorową mądrością” doktryny i orzecznictwa ${ }^{5}$. Zresztą samo prawo ze swej istoty formułuje owe problemy, nadając im odpowiednią rangę, sytuując je w różnych (co do hierarchii) aktach prawa pod postacią norm ogólnie obowiązujących, a także wyraża $\mathrm{w}$ ramach tych norm określone wartości będące odzwierciedleniem publicznych (społecznych) interesów i postulatów.

Usystematyzowanie rozważań o prawie jest możliwe, gdy nakreśla się najpierw obszar badawczy, aby rozważania te nie były dokonywane na zbyt ogólnym i zarazem zbyt abstrakcyjnym poziomie. Pomocne w tej kwestii może być oparcie się na proponowanym przez filozofię ogólną schemacie podziału materii uznawanej za podłoże znajdowania problemów o odpowiednim ciężarze gatunkowym i sklasyfikowanych rodzajowo (przedmiotowo). Jest to podział na naukę (wiedzę) dotyczącą: bytu (ontologia), poznawania (epistemologia), wartości (aksjologia) oraz metod (metodologia). Mogą to być rozważania dotyczące prawa w ogólności, lecz także (a może przede wszystkim) odnoszące się do poszczególnych dyscyplin dogmatycznych, w tym prawa gospodarczego publicznego.

Niezbędne jest przy tym sformułowanie i postawienie pytań nakierowanych na potrzebę ustalenia przedmiotu wskazanych obszarów badawczych — w sferze: ontologii - istota i zakres prawa gospodarczego publicznego, epistemologii — możliwość poznania funkcjonowania tej dyscypliny, metodologii — sposoby badania danej dogmatyki, a także aksjologii — podstawowe idee i wartości leżące u podstaw prawa gospodarczego publicznego ${ }^{6}$.

\section{Dlaczego aksjologia?}

Jak można zasadnie zauważyć, ustalenia dotyczące istoty i zakresu prawa gospodarczego publicznego nie rozwiązują żadnego większego problemu o szer-

5 Zob. R.A. Tokarczyk, Rozważania o sprawiedliwości w świetle filozofii prawa, Lublin 1993, s. 7.

${ }^{6}$ Zob. R.A. Tokarczyk, Filozofia prawa w perspektywie prawa natury, Białystok 1998, s. 19 n.; M. Zirk-Sadowski, Wprowadzenie do filozofii prawa, Kraków 2000, s. 24 n.; oraz M. Szyszkowska, Europejska filozofia prawa, Warszawa 1993, s. 2. 
szym znaczeniu społecznym, lecz mają wymiar głównie teoretyczny. Z ontologicznej perspektywy niewątpliwie ważne jest wyznaczenie zakresu prawa gospodarczego publicznego, choć jest to niezwykle utrudnione z uwagi na ,wyłaniające się" $\mathrm{z}$ tej dogmatyki kompleksy nowych zagadnień i lokowanie ich w wyodrębnionych systemach normatywnych.

Z kolei udzielenie odpowiedzi na pytania stawiane na gruncie epistemologii (odnośnie do możliwości poznania funkcjonowania przedmiotowej dyscypliny) oraz metodologii (co do sposobów jej badania) prowadziłoby do osiągnięcia bardzo podobnego rezultatu jak w wypadku innych dziedzin prawa. Niejako na marginesie trzeba jednak zauważać cechy szczególne — de facto trudności w zakresie badania funkcjonowania prawa gospodarczego publicznego oraz mające wpływ na sposoby jego badania. U ich podstaw ulokowane są: duża fluktuacja przepisów (objawiająca się nie tylko wprowadzaniem do systemu normatywnego nowych aktów prawnych, lecz także dokonywaniem częstych zmian przepisów obowiązujących), nieprecyzyjność stosowanych pojęć i nazewnictwa, niewłaściwa harmonizacja treści poszczególnych aktów prawnych, nadmierna ekonomizacja prawa, a ponadto jego wielowątkowość i zbędna szczegółowość (co czyni z aktów prawnych niejednokrotnie akty instrukcyjne).

Nie negując potrzeby całościowej refleksji filozoficznej nad prawem gospodarczym publicznym, trzeba zauważyć, że punktem wyjścia tej refleksji powinna stać się aksjologia. Zdaje się ona najpełniej udzielać odpowiedzi na pytania odnoszące się do fundamentalnych problemów danej dogmatyki, a ich postawienie powinno, jak się wydaje, wyprzedzać inne badania i dywagacje odnoszące się do prawa gospodarczego publicznego. Zaznaczyć przy tym można, że przy wykorzystaniu aksjologii możliwe jest badanie funkcjonowania tej dogmatyki oraz ustalanie sposobów tego badania, a dodatkowo że to właśnie aksjologia uwidacznia specyfikę prawa gospodarczego publicznego jako dyscypliny traktującej o oddziaływaniu państwa na gospodarkę i relacjach między organami tego państwa a podmiotami działalności gospodarczej.

\section{Znaczenie wartości}

Wartości (będące przedmiotem aksjologii) pozostają w różnych relacjach z dyscyplinami dogmatycznymi. Wyróżnić można w tym zakresie cztery ujęcia modelowe. Model pierwszy zakłada, że podstawą rozważań o danej dogmatyce są własne, charakterystyczne dla tej dogmatyki wartości i to one przez „przeniknięcie" do wewnątrz odpowiedniej części systemu prawa (również prawa gospodarczego publicznego) przesądzają o jego specyfice, w tym o istocie, zakresie, konstrukcji wielu instytucji tego prawa, a także o jego zasadach. Ponieważ poszczególne dogmatyki są integralnymi częściami systemu prawa, kolejny model 
przyjmuje potrzebę (konieczność) uwzględniania w ramach danej dogmatyki wartości uniwersalnych dla całego systemu prawa (model „od zewnątrz”). Następny model zaś sprowadza się do przyjęcia założenia, że aksjologia powinna służyć analizie dogmatyczno-prawnej konkretnych problemów wymagających rozstrzygnięcia. Wreszcie czwarty model oznacza akceptację instrumentalnego traktowania wartości jako czynników niezbędnych do przeprowadzenia wspomnianej analizy i wykładni ogółu przepisów danej dogmatyki ${ }^{7}$.

Traktowanie o wartościach należy łączyć z ustaleniami dotyczącymi tego, czy zostały one odpowiednio określone (nazwane) przez ustawodawcę, a zatem czy istnieje możliwość ich identyfikacji w kontekście nie tyko całej dyscypliny, ale przede wszystkim konkretnych aktów prawnych. Możliwe jest twierdzenie odnośnie do potrzeby wyrażenia ich wprost $\mathrm{w}$ akcie prawnym $\mathrm{i}$ jednocześnie uznania ich za element systemu prawa, choć zarazem twierdzeniu takiemu można przeczyć, przyjmując, że ich związek z prawem jest jedynie logiczny ${ }^{8}$. Ich identyfikacja nie zawsze jest możliwa, gdy co najwyżej zakłada się ich istnienie, wywodzi je z określonego katalogu wartości, ewentualnie są one określone jedynie implicite. Z punktu widzenia badającego prawo i szukającego leżących u jego podstaw wartości oraz dla stosującego przepisy i posługującego się różnymi rodzajami wykładni owa identyfikacja jest jednak niezwykle istotna, albowiem identyfikacja, a właściwie uznanie za „istniejącą” konkretnej wartości, przekłada się na ocenę prawa i jego instytucji oraz na efekt wykładni.

Jeżeli wartości w dowolny sposób uwzględniane są przez ustawodawcę na etapie tworzenia prawa lub jego zmian, są one przejawem określonych preferencji tego ustawodawcy. Można tu wskazać choćby na: wydzielenie preambuły danego aktu prawnego i wypełnienia jej odpowiednią treścią, ukształtowanie merytorycznego związku takiego aktu z innymi zbiorami przepisów, wyznaczenie celów regulacji prawnej czy nadanie konstrukcjom danej dogmatyki określonego, pożądanego kształtu. Te preferencje oznaczają wytyczenie, a następnie realizację modelu prawa odpowiadającego wartościom.

Wartości są podstawą, a zarazem punktem wyjścia formułowania zasad poszczególnych dogmatyk, w tym prawa gospodarczego publicznego. Jednocześnie to owe zasady wartości ukierunkowują, to znaczy wskazują odpowiedni obszar ich odniesienia. Może to być na przykład sfera stanowienia prawa, podejmowanie działalności gospodarczej, reglamentacja lub kontrola. Zasady są nośnikami wartości, nadają wartościom charakter normatywny, wprowadzają je w obszar prawa, jego systematyki i podziałów.

7 Zob. J. Zajadło, Filozofia a nauki prawne - słowo wstępne, „Gdańskie Studia Prawnicze” 18. Filozofia dogmatyk prawniczych, 2007, s. 8-10.

${ }^{8}$ W tej kwestii zob. M. Kordela, Zasady prawa jako normatywna postać wartości, „Ruch Prawniczy, Ekonomiczny i Socjologiczny" 2006, nr 1, s. 47. 
Daje się zauważyć zarówno pośredni, jak i bezpośredni wpływ wartości na prawo. Pośredniość oddziaływania można stwierdzić głównie na etapie tworzenia prawa, bezpośredniość zaś przede wszystkim, gdy w grę wchodzi wszelka interpretacja prawa obowiązującego i jego stosowanie.

Spoglądając na prawotwórstwo w zakresie poszczególnych dogmatyk, w tym w zakresie prawa gospodarczego publicznego, trzeba skonstatować, że nie zawsze wartości, nawet uznane przez ustawodawcę i wprowadzone do systemu prawa (expressis verbis lub choćby implicite), znajdują bezpośrednie odzwierciedlenie w tworzonym prawie i jego konstrukcjach normatywnych. Wartości częstokroć pozostają deklaracjami po stronie ustawodawcy, ten zaś na tych deklaracjach poprzestaje. Problem jest niejako rozwiązany, bo przecież nastąpiło wytyczenie (wskazanie) kierunku, określenie intencji na podstawie wartości, brakuje jednak normotwórstwa odpowiadającego jednoznacznie za realizację zadeklarowanej wartości. Jest również tak, że normy danego systemu prawa nie zawsze znajdują odpowiednie uzasadnienie aksjologiczne ${ }^{9}$, choć zależy to także od stopnia uporządkowania systemu wartości przez dokonanie odpowiedniego wyboru określonych wartości i przyjęcia ich za „własne”, godne uznania za istotne dla prawa, akceptowalne społecznie, realne ekonomicznie itp.

Interpretacja prawa natomiast, jeśli odwołuje się do wartości jako czynnika oceniającego badane normy, wiąże się z bezpośrednim „wykorzystaniem” danej (danych) wartości. Niezaprzeczalnie wartości przyczyniają się do kierunkowej interpretacji pojęć niedookreślonych oraz klauzul generalnych. Warunkiem służącym zasadności i legalności takiej wykładni jest niewątpliwie uznanie określonej wartości za element systemu prawa lub przynajmniej niekwestionowanie takiej wartości jako przynależnej do pozaprawnego systemu wartości.

Rolą wartości jest w szczególności skłanianie adresatów prawa do jego przestrzegania. Jest to aktualne przy założeniu, że adresaci prawa wartości te znają, akceptują i utożsamiają się z nimi. W ten sposób dochodzi też do sytuacji, w której wartości umacniają autorytet ustawodawcy. To bowiem ustawodawca stworzył prawo oparte na wskazanych wartościach, co zatem oznacza, że ten ustawodawca, analogicznie jak adresaci prawa, utożsamia się z tymi wartościami. Patrząc z perspektywy prawa gospodarczego publicznego, należy uznać, że wartości określają ład gospodarczy państwa i relacje między administracją gospodarczą a przedsiębiorcami. Akceptacja dla tych wartości może i powinna przyczyniać się do stworzenia harmonijnego, przyjaznego dla podmiotów działalności gospodarczej i odpowiadającego interesowi publicznemu ładu normatywnego w gospodarce.

9 Zob. Z. Ziembiński, Wartości konstytucyjne. Zarys problematyki, Warszawa 2003, s. 7. 


\section{4. Źródła i katalog wartości}

Katalog wartości ma bardzo zróżnicowaną zawartość. Umieszczenie w nim poszczególnych wartości zależy od tego, jakie cechy przypisuje się owym wartościom oraz które z nich traktujemy jako odnoszące się do prawa w ogóle lub do różnych jego dogmatyk. Formułując katalog wartości, niewątpliwie trzeba mieć na względzie akceptowalność, zarówno po stronie ustawodawcy, jak i adresatów prawa, choć bezspornie to od ustawodawcy zależy, które z wartości zostaną „wprowadzone" do systemu prawa i w jego ramach uznane.

Istotne znaczenie ma, jak się wydaje, źródło, z którego można wywodzić daną wartość, ponieważ może być ono potraktowane jako kryterium oceny celu posługiwania się daną wartością na gruncie prawa oraz oceny efektu, jaki zamierza się osiągnąć przy wykorzystaniu takiej wartości. W katalogu wartości przypisywanych prawu ${ }^{10}$ wymienia się wartości o dużym stopniu ogólności, co ma służyć ich uniwersalnemu zastosowaniu, czyli możliwości ich odniesienia do poszczególnych dogmatyk, w tym prawa gospodarczego publicznego. Są to przykładowo: legalność i praworządność, elastyczność stosowania prawa, luzy decyzyjne w stosowaniu prawa oraz pewność stosowania prawa. Jeżeli katalog wartości ma pozostawać w odpowiednich relacjach z konkretną dogmatyką, wtedy zazwyczaj jest on rozszerzany o wartości szczególne, właściwe tylko wybranej dogmatyce.

Nie sposób odpowiedzieć na pytanie, czy formułowane katalogi (zestawienia) wartości wykazują się kompletnością, a także czy wymagają odpowiednich uzupełnień lub korekt ${ }^{11}$. Uzasadnione w tym zakresie jest każde twierdzenie, analogicznie jak w wypadku źródeł wartości. Jeśli zakłada się, że źródłem wartości może być nie tylko prawodawca, lecz że można wartości istotne dla prawa wywodzić także z zestawów (zbiorów) pozaprawnych, w efekcie katalog wartości znajdujących zastosowanie w systemach prawa może być niezwykle obszerny. Oznacza to również możliwość wystąpienia sprzeczności pomiędzy poszczególnymi wartościami, co jest najbardziej prawdopodobne, gdy prawodawca umożliwia adresatom norm prawnych i stosującym prawo powoływanie się na wartości niewskazane wprost przez tego prawodawcę. Jest tak również wtedy, gdy prawodawca wprowadza do systemu prawa wartości z sobą sprzeczne, a także gdy przyczyną sprzeczności jest niewystępowanie korelacji pomiędzy deklarowanymi wartościami, których nie potwierdzają przepisy prawa, lub wręcz wbrew danym wartościom tworzone jest prawo bądź prowadzona polityka w zakresie normotwórstwa.

10 Zob. L. Leszczyński, [w:] A. Korybski, L. Leszczyński, Stanowienie i stosowanie prawa. Elementy teorii, Warszawa 2015, s. 166 n.

11 M. Zdyb uważa, że w katalogu wartości, które należy wiązać z prawem gospodarczym publicznym, brakuje podstawowej wartości, jaką jest pewność prawa - M. Zdyb, G. Lubeńczuk, A. Wołoszyn-Cichocka, Prawo przedsiębiorców. Komentarz, Warszawa 2019, s. 20 n. 
Chyba najczęściej wartości przyjmowane i akceptowane (z różnych zresztą powodów) przez ustawodawcę umiejscowiane są w preambułach aktów prawnych $^{12}$. W zależności od tego, jakie miejsce w systemie prawa zajmuje dany akt prawny i jakie ma znaczenie dla regulacji określonych stosunków społecznych (w tym gospodarczych), wartościom nadawana jest odpowiednia ranga i wskazywany zakres ich oddziaływania na prawo. Bywa jednak i tak, że zakres ten jest trudny do określenia, co ma miejsce w sytuacji, gdy ustawodawca traktuje wartości wyłącznie jako deklaracje, niewsparte normami prawa i nieodzwierciedlone w konstrukcjach prawa pozytywnego.

Znaczenie, istotę, sens i treść poszczególnych wartości tłumaczyć (interpretować) mogą różne czynniki. Może to czynić przede wszystkim prawodawca, dokonując takiej interpretacji w drodze tworzenia prawa odpowiadającego wartościom. Czynić to mogą także stosujący prawo (w tym orzekający), powołując się $\mathrm{w}$ toku stosowania przepisów na określone wartości, jednak — jak się wydaje — przy założeniu, że wartości te prawodawca uznał i wprowadził do systemu prawa. Wreszcie thumaczenie wartości to domena doktryny, przy czym w takich wypadkach niewątpliwie mamy do czynienia z subiektywnymi refleksjami badających prawo.

Refleksja nad wartościami mającymi swe korzenie w normach o charakterze społecznym (w tym normach moralnych, obyczajach, etyce, zwyczajach) jest, jak można zauważyć, dążeniem do humanizacji prawa. Analogicznie można skonstatować, że dywagacje w przedmiocie wartości ekonomicznych zmierzają ku temu, aby prawo uwzględniało również potrzeby i realia gospodarcze.

\section{Wartości a prawo gospodarcze publiczne}

Do poszczególnych dyscyplin dogmatycznych, w tym do prawa gospodarczego publicznego, należy odnosić uniwersalne wartości leżące u podstaw prawa w ogólności, lecz także wartości, które w szczególny sposób kształtują tę właśnie dogmatykę. Mają one wpływ w pierwszej kolejności na ustawodawstwo i jego kierunki, a następnie na stosowanie prawa gospodarczego publicznego i wykładnię tego prawa. Wydaje się przy tym, że istnieją też wartości natury fundamentalnej dla prawa gospodarczego publicznego, określające istotę omawianej dyscypliny, a w konsekwencji także jej zakres. Należą do nich wolność działalności gospodarczej i interes publiczny (społeczny).

Wolność działalności gospodarczej może być postrzegana w powiązaniu z treścią art. 20 i 22 Konstytucji RP, a więc w związku z zasadą społecznej gospodarki rynkowej oraz ograniczeniami wolności w związku z ustawową reglamentacją.

12 Zob. M. Kordela, Systemowość aksjologiczna prawa, „Przegląd Prawa i Administracji” 104, 2016, s. 6. 
Wolność trzeba jednak dostrzegać również w obszarze podejmowania, wykonywania i zakończenia działalności gospodarczej, czyli opierając się na przepisach ustawy Prawo przedsiębiorców, choć oczywiście także na przepisach normujących mechanizm konkurencyjny (wolność przez wytyczanie jej granic), a nawet normach systemu zamówień publicznych (wykorzystanie instrumentów wolnościowych konkursu ofert, przetargu, umowy — do regulacji administracyjnej wydatkowania środków publicznych). Wartość ta kształtuje prawa podmiotowe przedsiębiorców, choć jednocześnie - w odniesieniu do państwa — nadaje formę publicznemu prawu podmiotowemu, zaznaczając granice ingerencji (oddziaływania) państwa na gospodarkę, a tym samym granice swobód przedsiębiorców ${ }^{13}$.

Drugą fundamentalną dla prawa gospodarczego publicznego wartością jest interes publiczny (społeczny). Stanowi on istotną przesłankę ograniczania wolności działalności gospodarczej na tle art. 22 Konstytucji RP, ale przede wszystkim jest wytyczną kierunkową dla systemu gospodarki, która powinna być rynkowa, a zarazem społeczna. Normy prawa gospodarczego publicznego powinny być zatem ukierunkowane na realizację wskazanej wartości, a tym samym powinny zapewniać jej należytą ochronę ${ }^{14}$. Jak daje się zauważyć, ustawodawca jedynie wskazuje jednak na zależność przyjmowanych rozwiązań prawnych od wartości, jaką jest interes publiczny, nie odwołując się do treści tej wartości, wobec czego nie w pełni wiadomo i rozpoznano, co leży w interesie publicznym, czyli co jest jego treścią.

Respektowanie i uwzględnianie interesu publicznego, zarówno w procesie tworzenia, jak i stosowania prawa, nie może przy tym kolidować z wolnością działalności gospodarczej. Obydwie te wartości nie mogą się wykluczać przede wszystkim na tle konstytucyjnej zasady społecznej gospodarki rynkowej. Wskazuje ona na wolność działalności gospodarczej jako filar (jedną z podstaw) gospodarki, a zarazem zobowiązuje (państwo) do oddziaływania na tę gospodarkę $\mathrm{w}$ interesie publicznym (społecznym). Taka konstrukcja normatywna oparta na wskazanych wartościach jest fundamentem prawa gospodarczego publicznego.

\section{Na zakończenie}

Wydaje się, że wartości powinny pozostawać w ścisłej relacji z normami prawa. Tylko wtedy możliwe jest bowiem ustalenie, jaki wpływ na prawo mają konkretne wartości. Postulat ten nieczęsto jest doceniany przez ustawodawcę lub

13 Na temat wolności działalności gospodarczej zob. np. A. Dobaczewska, [w:] A. Dobaczewska, A. Powałowski, H. Wolska, Nowe prawo przedsiębiorców, Warszawa 2018, s. 41-51; E. Komierzyńska-Orlińska, [w:] Konstytucja biznesu. Komentarz, red. M. Wierzbowski, Warszawa 2019, s. $40-47$.

14 Por. R. Blicharz, M. Kania, Klauzula interesu publicznego w publicznym prawie gospodarczym, „Przegląd Ustawodawstwa Gospodarczego” 2010, nr 5, s. 12. 
po prostu przez niego nieuwzględniany. Oznacza to usunięcie problematyki aksjologicznej z pola rozważań o prawie. Pozostawianie wartości jako wyłącznie deklaracji niewspartych normami jest tego przejawem.

Wartościom zagraża także w szczególności: nadmierna ekonomizacja prawa (skutkująca dehumanizacją), upolitycznienie ustawodawcy (objawiające się dążeniem do realizacji celów doraźnych, wytyczonych przez partie polityczne, kosztem wartości), niedoskonałość prawa związana z niewłaściwą techniką legislacyjną (wartości tylko w preambule), niekonsekwencje w zakresie wprowadzania nowych rozwiązań prawnych (niejednoznaczne definicje, nieopracowanie logicznych, poprawnych merytorycznie konstrukcji prawnych) oraz nieodwoływanie się do zadeklarowanych wartości (na przykład nieuzasadnianie reglamentacji określoną postacią interesu publicznego).

Prawo powinno chronić wartości, na których się opiera, jest ono bowiem tymi wartościami uzasadnione. W prawie gospodarczym publicznym ich rola sprowadza się do wyraźnego wpływu na podejmowanie, wykonywanie i zakończenie działalności gospodarczej oraz na relacje między organami państwa a podmiotami działalności gospodarczej. Warto zatem, jak się wydaje, podejmować rozważania o prawie gospodarczym publicznym w kontekście aksjologicznym, być może na potrzeby silniejszego zaakcentowania odrębności tej dyscypliny, a także jej wewnętrznej konsolidacji, spójności oraz poprawności merytorycznej i formalnej.

\section{Bibliografia}

Blicharz R., Kania M., Klauzula interesu publicznego w publicznym prawie gospodarczym, „Przegląd Ustawodawstwa Gospodarczego" 2010, nr 5.

Dobaczewska A., [w:] A. Dobaczewska, A. Powałowski, H. Wolska, Nowe prawo przedsiębiorców, Warszawa 2018.

Grabowski J., [w:] System Prawa Administracyjnego, t. 8a. Publiczne prawo gospodarcze, red. J. Grabowski, L. Kieres, A. Walaszek-Pyzioł, Warszawa 2013.

Jaśkiewicz Z., Prawo zarządzania gospodarka narodowa (prawo gospodarcze publiczne), Gdańsk 1988.

Komierzyńska-Orlińska E., [w:] Konstytucja biznesu. Komentarz, red. M. Wierzbowski, Warszawa 2019.

Kordela M., Systemowość aksjologiczna prawa, „Przegląd Prawa i Administracji” 104, 2016.

Kordela M., Zasady prawa jako normatywna postać wartości, „Ruch Prawniczy, Ekonomiczny i Socjologiczny" 2006, nr 1.

Kosikowski C., Prawo gospodarcze publiczne (część ogólna), Łódź 1992.

Kosikowski C., Prawo zarządzania gospodarka narodowa, Warszawa 1991.

Leszczyński L., [w:] A. Korybski, L. Leszczyński, Stanowienie i stosowanie prawa. Elementy teorii, Warszawa 2015.

Madey M., Stelmachowski A., Zarys prawa gospodarczego, Warszawa 1970.

Strzyczkowski K., Prawo gospodarcze publiczne, Warszawa 2011. 
Szyszkowska M., Europejska filozofia prawa, Warszawa 1993.

Tokarczyk R.A., Filozofia prawa w perspektywie prawa natury, Białystok 1998.

Tokarczyk R.A., Rozważania o sprawiedliwości w świetle filozofii prawa, Lublin 1993.

Włodyka S., Prawo gospodarcze. Zarys systemu. Część ogólna, Warszawa 1981.

Zajadło J., Filozofia a nauki prawne - słowo wstępne, „Gdańskie Studia Prawnicze” 18. Filozofia dogmatyk prawniczych, 2007.

Zdyb M., Lubeńczuk G., Wołoszyn-Cichocka A., Prawo przedsiębiorców. Komentarz, Warszawa 2019.

Ziembiński Z., Wartości konstytucyjne. Zarys problematyki, Warszawa 2003.

Zirk-Sadowski M., Wprowadzenie do filozofii prawa, Kraków 2000.

\section{Introduction to axiology of public economic law}

\section{Summary}

A philosophical reflection is needed on public economic law, and in particular the determination of the values underlying this dogma. The values should first be properly identified and their sources determined. The problem is their degree of acceptance by the legislator expressed in the content of statutory norms and the role and importance of values in the process of applying the law. Values determine governance in the area of the economy, affect relations between state authorities and entrepreneurs, as well as the sphere of business activity. They constitute a necessary premise for formulating the principles of law. The freedom to conduct business activity properly configured with the need to pursue the public interest are the values characterising and distinguishing public economic law.

Keywords: axiology, values, public economic law, principles of law, entrepreneurs, legislator. 